\title{
PHYTOCHEMICAL SCREENING, ANTIOXIDANT, AND CYTOTOXICITY OF Zamioculcas zamiifolia ROOT EXTRACT
}

\author{
Rini Muharini ${ }^{{ }^{*}}{ }$ Masriani $^{1}$, Rudiyansyah ${ }^{2}$ \\ ${ }^{1}$ Department of Chemistry Education, Faculty of Teacher Training and Education, Tanjungpura \\ University, Jl. Prof. H. Hadari Nawawi, Pontianak, 74014, Indonesia \\ ${ }^{2}$ Department of Chemistry, Faculty of Mathematics and Sciences, Tanjungpura University, Jl. Prof. Dr. \\ H. Hadari Nawawi, Pontianak, 74014, Indonesia \\ "Corresponding author: rini.muharini@chem.edu.untan.ac.id
}

\begin{tabular}{l}
\hline ARTICLE INFO \\
Article history: \\
Received 07 July 2018 \\
Accepted 19 December \\
2018 \\
Available online \\
30 December 2018 \\
Keywords: \\
phytochemical \\
screening, anti- \\
oxidant, cytotoxicity, \\
Zamioculcas zamiifolia \\
\end{tabular}

\begin{abstract}
Zamioculcas zamiifolia is an ornamental plant that had been used pharmacologycally as a traditional medicine plant. The aims of this research were to investigate the phytochemistry of $n$-hexane, chloroform and methanol extracts from the roots of $Z$. zamiifolia and to evaluate their biological activities as antioxidant and cytotoxic. All extracts were screened phytochemically using specific reagents and TLC technique to reveal the major component of each extract. The chloroform was obtained as the highest quantity of extract which gave positive test for steroids and flavonoids. All extracts were tested for their antioxidant activity using DPPH method and for their cytotoxic activity against two types of human cancer cell lines, HepG2 and T47D, and normal African green monkey kidney ephitelial cell lines, Vero. The methanol and chloroform extract exhibited antioxidant activity with $\mathrm{AA}_{50}$ values of 180.0 and $431.5 \mu \mathrm{g} / \mathrm{mL}$, respectively. Chloroform and methanol extracts showed potencial and moderate cytotoxicity towards T47D cell line with $\mathrm{IC}_{50} 433.1$ and $461.1 \mu \mathrm{g} / \mathrm{mL}$, respectively. None of the extracts was toxic against HepG2 and Vero cell lines.

(C) 2018 IJoPAC. All rights reserved
\end{abstract}

\section{Introduction}

Zamioculcas zamiifolia is widely known by Indonesian as ornamental plants, with local name Dolar plants. Z. zamiifolia plant is an Araceae family, that is known for its toxicity ${ }^{[1],[2]}$. With regard to their close relationship, $Z$, zamiifolia were assumed to be toxic as well. Literature study showed that the leaves of $Z$. zamiifolia are able to absorb the volatile organic compounds, such as benzene, toluene, ethylbenzene, and xylene from air ${ }^{[3],[4]}$. These facts concern people who utilize this plant as an ornamental plant.

This plant has been utilized externally as traditional medicine by some local people from other parts of the globe. Malawian people use the leaves of $Z$. zamiifolia as earache on children, meanwhile the roots are used for treating gastric problems by Sukuma people in Tanzania. Previously, the research group of Le Moullec (2015) reported that the leaf extract of Z.zamiifolia did not show cytotoxicity against Artemia salina, using brine shrimp lethality (BSL) method ${ }^{[5]}$. This latest result dissmissed the assumption of the toxicity of Z.zamiifolia leaves. Moreover, Le Moullec. (2015) obtained secondary metabolites from the leaves extract of $Z$. zamiifolia, 
including phenolic acids, phenylpropanoids, and flavonoids. Nevertheless, no phytochemical studies yet exist hitherto to reveal the secondary metabolite contents from the roots of $Z$. zamiifolia as well as their toxicity.

This paper describes the phytochemical study of $n$-hexane, chloroform, and methanol extracts of $Z$. zamiifolia roots. All extracts had been evaluated for their antioxidant activity using DPPH method and their cytotoxicity against two types of human cancer lines, HepG2 and T47D, and normal African green monkey kidney ephitelial Vero normal cell line using MTT method.

\section{Material and Methods}

\subsection{General experiment}

A Spectrophotometer Ultra Violet (UV) dual beam was used to measure the concentration of anti-oxidative extracts using DPPH method. Thin Layer Chromatography (TLC) aluminium plate coated with silica gel 60 F254 (Merck Millipore, USA) was used as a tool to monitor extraction process and to identify the type of secondary metabolites. The chromatograms were detected using $\mathrm{CeSO}_{4}$ as spray reagent and under UV at wavelength $254 \mathrm{~nm}$. Evaporating process was carried out using rotary vacuum evaporator (Buchi, Germany). All solvents used were distilled before extractions.

\subsection{Plant material}

The roots of Zamioculcas zamiifolia were collected on May, 2017, in Pontianak. The plant voucher was recorded and stored at chemistry laboratory, FKIP, UNTAN, Pontianak.

\subsection{Experimental procedures}

\subsubsection{Extractions}

The roots of $Z$. zamiifolia were air dried and powdered. The powdered root of $Z$. zamiifolia was weighed, extracted with $n$-hexane for $3 \times 24 \mathrm{~h}$, and filtered to obtain a $n$-hexane extract. Residu was macerated further using chloroform for $3 \times 24 \mathrm{~h}$ and filtered to give a chloroform extract. Its residu was macerated with methanol for $3 \times 24 \mathrm{~h}$ and filtered to obtain a methanol extract. Each extract was concentrated using rotary vacuum evaporator to give $n$-hexane (1.8 g), chloroform (3.6 g), and methanol extracts $(0.7 \mathrm{~g})$.

\subsubsection{Phytochemical analyses}

Phytochemical analyses were conducted to each extract using specific reagents, including Liebermann-Burschad, Salwkosky, Shinoda, Mayer, and $\mathrm{FeCl}_{3}$ 5\%. Spray reagent $\mathrm{CeSO}_{4}$ 1,5\% followed by heating was used to detect spots on TLC ${ }^{[6]}$.

\subsubsection{Antioxidant test}

The antioxidant activity test was performed toward n-hexane, chloroform and methanol extracts, using qualitative and quantitative 2,2-diphenyl-1-picrylhydrazyl (DPPH) method. The dibutylhydroxytoluene (BHT) was used as positive control. The DPPH method in this research was modified from the anti-oxidant protocol of Henrique H. Moresco (2011). $1 \mathrm{mg}$ DPPH was dissolved into $50 \mathrm{~mL}$ methanol to give concentration of $20 \mu \mathrm{g} / \mathrm{mL}$ then stored in dark room ${ }^{[6],[7],[8]}$.

a. Qualitative Antioxidant test

$1 \mathrm{mg}$ of each extract and a positive control were dissolved in soluble solvent and applied on TLC plate. Those spots were sprayed with the DPPH solution and immediately stored in dark room. After 30 minutes, the TLC plate was observed for white spots indicating for anti-oxidant activity.

b. Quantitative Antioxidant test

$10 \mathrm{~mL}$ stock solution of each extract was prepared in methanol, meanwhile $50 \mathrm{~mL}$ stock solution dibutylhydroxytoluene (BHT) as a positive control was prepared with concentration 0.5 $\mathrm{mg} / \mathrm{mL} .1 \mathrm{~mL}$ of each extract (in concentration $5-200 \mu \mathrm{g} / \mathrm{mL}$ ) was added by $2 \mathrm{~mL} \mathrm{DPPH}$ in methanol $(0.004 \%)$. The mixtures were homogenized and stored in dark room for 30 minutes at room temperature. The absorbance of each sample was measured using spectrophotometer UV dual beam at wavelength $517 \mathrm{~nm}$ and then converted to antioxidant activity (\%) using formula as follows: 


$$
\mathrm{AA} \%=\frac{[\text { Abs control }- \text { Abs sample }]}{\text { Abs control }} \times 100 \%
$$

$2 \mathrm{~mL}$ methanol was used as a blank solution (Abs blank). The mixture of $2 \mathrm{~mL}$ DPPH (0.004 \%) and $1 \mathrm{~mL}$ methanol was used as a control solution (Abs control). The anti-oxidant activity was expressed in concentration needed for reducing 50\% DPPH absorbance (AA50). The AA50 value was determined through linier regression between the percentages of DPPH absorbance reduction as a function of sample concentration. This experiment was performed tripled and the same protocol was performed toward the positive control (BHT) ${ }^{[6],[7]}$.

\subsubsection{Cytotoxicity test}

Human cancer cell lines of HepG2, T47D, and normal cell lines of Vero were provided by Parasitology Laboratory, Faculty of Medicine, Gadjah Mada University. In vitro cytotocity test was conducted toward these lines using modified MTT method ${ }^{[8]} .100 \mu \mathrm{L}$ cell suspension $(1 \mathrm{x} 104$ cell $/ \mathrm{mL}$ ) was placed into micro plate 96 -well. After $24 \mathrm{~h}$ incubation, each extract with concentration $31.25,62.5,125,250$, and $500 \mathrm{ppm}$ was added to the cells and incubated for $24 \mathrm{~h} .110 \mu \mathrm{L}$ MTT reagent $(5 \mathrm{mg} / \mathrm{ml})$ in PBS was added into each well and incubated for another $4 \mathrm{~h}$ at $\mathrm{CO} 2$ incubator. Each well was added $100 \mu \mathrm{L}$ SDS $10 \%$ in $\mathrm{HCl} 0,01 \mathrm{~N}$ to dissolve purple formazan. Cell absorbance was measured using ELISA reader at wavelength $595 \mathrm{~nm}$. Cell viability was calculated as the percentage of cytotoxicity using equation as follows:

$\%$ Cytotoxicity $=\frac{(\text { Absorbance of cell without treatment-Absorbance cell with treatment })}{(\text { Absorbance of cell without treatment })} \times 100 \%$

Furthermore, the selectivity of each extract to the cell lines tested was determined as Selectivity Index (SI), which is a ratio of the cytotoxicity in Vero normal cell line (IC50 normal cell) to HepG2 or T47D cancer cell line $\left(\mathrm{IC}_{50}\right.$ cancer cell). When the extract has SI value higher than 3 , it will be considered to have high selectivity ${ }^{[10]}$.

\section{Results and Discussion}

The dried root of $Z$. zamiifolia (209.5 g) was extracted for $3 \times 24 \mathrm{~h}$ using $n$-hexane, chloroform, and methanol, respectively and followed by evaporating using rotary vacuum evaporator to give $n$ hexane (1.8 g), chloroform ( $3.6 \mathrm{~g})$, and methanol $(0.7 \mathrm{~g})$ extracts. These results showed that the highest content of secondary metabolites was in chloroform extract, assuming that the secondary metabolites contained in the root extract of Z.zamiifolia were mostly semi polar compounds (Table 1).

Table 1. Rendement results for $n$-hexane, chloroform, and methanol extracts

\begin{tabular}{lcc}
\hline Extract & $\begin{array}{l}\text { Weight } \\
\text { (gram) }\end{array}$ & Rendement (\%) $^{\mathbf{a}}$ \\
\hline n-hexane & 1.80 & 0.87 \\
chloroform & 3.58 & 1.74 \\
methanol & 0.65 & 0.32 \\
\hline \multicolumn{2}{r}{ Initial weight of Zamioculcas zamiifolia roots $=209.5$ gram }
\end{tabular}

Phytochemical screening towards each extract were carried out using specific reagents and spray reagent $\mathrm{CeSO} 41,5 \%$ on TLC. Based on phytochemical analysis, $n$-hexane extract showed the presence of steroids and triterpenoids. Positive results were also showed by chloroform extract toward Salkowsky and Shinoda reagents, indicating the presence of steroids and flavonoids. Further, the methanol extract gave positive results for triterpenoids, polyphenolics, and flavonoids. It seems that polyphenolics and flavonoids are the main compounds in semipolar and polar extracts. Previously, some flavonoids and polyphenolics were isolated from the extract of $Z$. zamiifolia 
leaves ${ }^{[5]}$. Thus, the similar compounds might be found from the roots of $Z$. zamiifolia. Meanwhile, the existence of alkaloid was not detected in in $Z$. zamiifolia roots. Phytochemical screening results using specific reagents were showed in Table 2.

Table 2. Phytochemical screening result for $n$-hexane, chloroform, and methanol extracts using specific reagents

\begin{tabular}{lccc}
\hline \multicolumn{1}{c}{ Specific Reagent } & $\begin{array}{c}\text { n-hexane } \\
\text { extract }\end{array}$ & $\begin{array}{c}\text { Chloroform } \\
\text { extract }\end{array}$ & $\begin{array}{c}\text { Methanol } \\
\text { extract }\end{array}$ \\
\hline Liebermann Burchard & + & - & + \\
Salwskosky & + & + & - \\
Shinoda & - & ++ & ++ \\
$\mathrm{FeCl}_{3}$ & - & - & ++ \\
Mayer & - & - & - \\
Dragendorff & - & - & - \\
\hline
\end{tabular}

Free radical-scavenging capacity (antioxidant activity) for each extract was evaluated using the DPPH method qualitatively and quantitatively. Qualitative TLC-DPPH test result for chloroform and methanol extracts showed that both extracts gave potential antioxidant activity in comparison to the positive control, ascorbic acid. Therefore, both extracts were evaluated further for antioxidant activity (AA50) using quantitative DPPH method. The result showed that chloroform and methanol extracts gave AA50 values of 431.5 and $180.1 \mathrm{ppm}$, respectively (Table 3), indicating that methanol extract was more active than chloroform extract. The polyphenolic and flavonoid compounds contained in methanol extract might be the responsible for the activity. This type of compounds has been reported to have antioxidant activity ${ }^{[3],[7]}$.

Table 3. Antioxidant activity and cytotoxicity for $n$-hexane, chloroform, and methanol extracts

\begin{tabular}{|c|c|c|c|c|c|c|}
\hline \multirow[t]{2}{*}{ Extract } & \multirow[t]{2}{*}{$\begin{array}{c}\text { Anti-oxidant } \\
\text { activity } \mathbf{A A}_{50}(\mathbf{p p m})\end{array}$} & \multicolumn{3}{|c|}{ Cytotoxicity $\left(\right.$ IC $\left._{50}\right)$} & \multicolumn{2}{|c|}{$\begin{array}{l}\text { Selectivity } \\
\text { Index (SI) }\end{array}$} \\
\hline & & $\begin{array}{c}\text { HepG2 } \\
(\mu \mathrm{g} / \mathrm{mL})\end{array}$ & $\begin{array}{c}\text { T47D } \\
(\mu \mathrm{g} / \mathrm{mL})\end{array}$ & $\begin{array}{c}\text { Vero } \\
(\mu \mathrm{g} / \mathrm{mL})\end{array}$ & HepG2 & T47D \\
\hline$n$-hexane & $\mathrm{dn}^{*}$ & $\mathrm{dn}^{*}$ & $\mathrm{dn}^{*}$ & $\mathrm{dn}^{*}$ & - & - \\
\hline chloroform & 431.5 & 3801.89 & 562.34 & 4677.35 & 1.22 & 8.32 \\
\hline methanol & 180.1 & 2818.38 & 645.65 & 1047.13 & 0.37 & 1.62 \\
\hline
\end{tabular}

*dn $=$ did not measure

The cytotoxicity test using the MTT assay was performed for chloroform and methanol extract of $Z$. zamiifolia roots against human cancer cell lines, HepG2 and T47D, and normal cell lines, Vero. As both extracts showed previously as anti-oxidant activity, it might involve the cytotoxicity of the extracts. The cytotoxicity test was not conducted for $n$-hexane extract, due to the solubility matter. Human cancer cell line HepG2 is cancer cells often used to predict the hepatotoxicity of material or compound. Hepatocarcinoma or heart cancer was found to be the sixth cancer disease case recently ${ }^{[11]}$. Human cancer cell line T47D is one of breast cancer cell types frequently used for testing cell ${ }^{[12]}$. According to Table 3 and Figure 1, chloroform and methanol extracts showed potencial and moderate cytotoxicity against T47D with 433.1 and $461.1 \mathrm{ppm}$, respectively ${ }^{10]}$. However, none of the extracts gave cytotoxicity against HepG2 and Vero cell lines. Thus, the above data indicated that the chloroform and methanol extracts of $Z$. zamiifolia roots were not deleterious toward hepatocellular carcinoma (Hep G2) and Vero normal cell lines. The SI values for each extract toward each cancer cell line were less than three, except for chloroform extract toward T47D cell line (Table 3). Previous study, the leaf extract of $Z$. zamiifolia and its isolated compounds were not toxic against brine shrimp Artemia salina ${ }^{[5]}$. Based on these results, it can be suggested that $Z$. zamiifolia is safe to be utilized as an ornamental plant. 

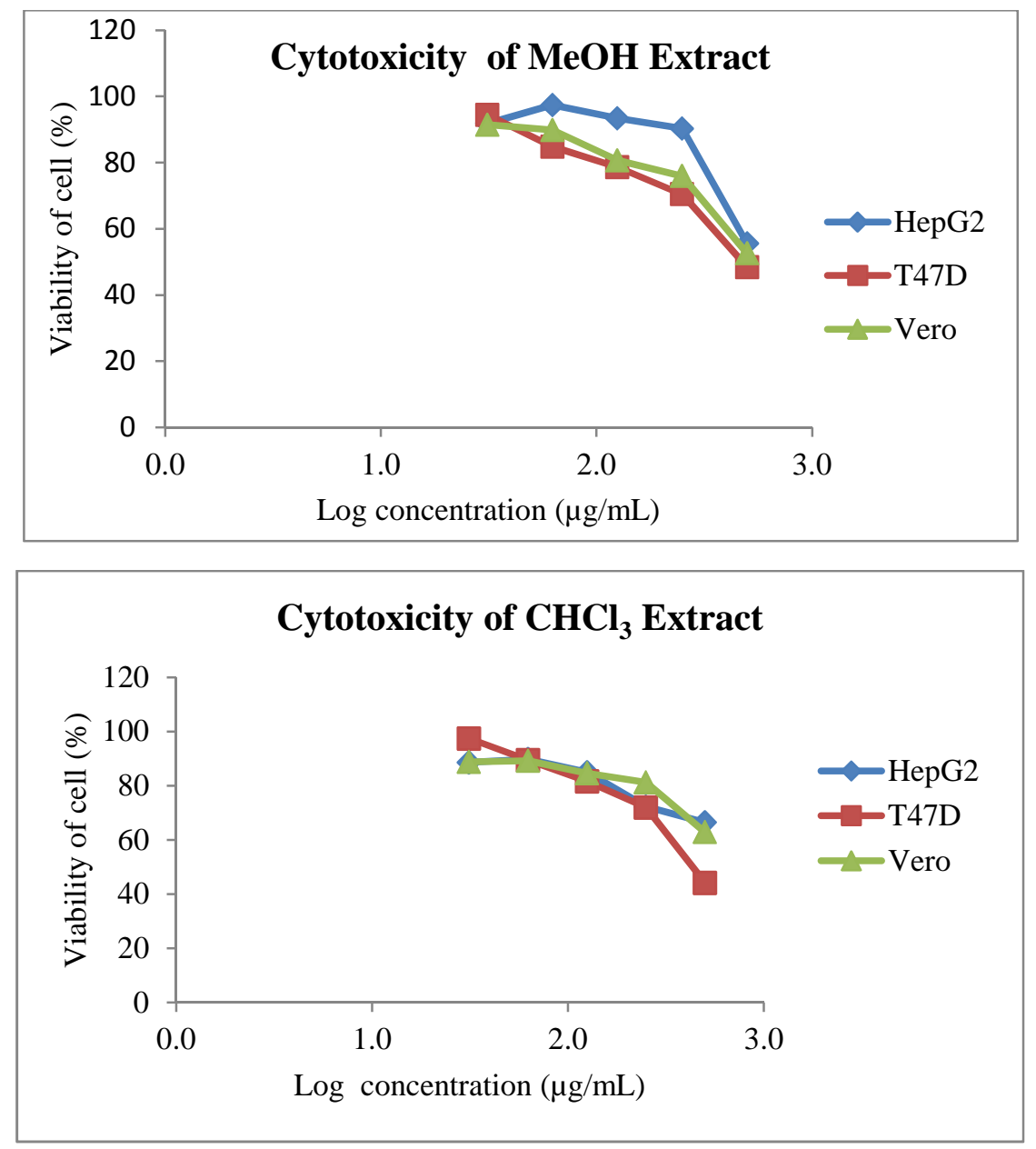

Figure 1. The curve of log concentration and viability of cell for methanol (a) and chloroform (b) extracts in HepG2, T47D, and Vero cell lines

\section{Conclusion}

The roots of $Z$. zamiifolia contained steroid, triterpenoid, flavonoid and polyphenolic. The highest content of extract was chloroform, in which flavonoids and steroids were detected. Based on the antioxidant and cytotoxicity results, the root extract of $Z$. zamiifolia is potential as a source of antioxidant, antihepatocarcinoma and does not show toxic to human normal cell. Further, the isolation of secondary metabolites from the chloroform extract of Z. Zamiifolia roots is under progress.

\section{Acknowledgement}

RM wishes to thank to the Faculty of Teacher Training and Education, Tanjungpura University, for the PNPB FKIP UNTAN Grant to this research. RM appreciates greatly to Fransiskus Sabianto and Deden Ardiyansyah, two undergraduate students of FKIP UNTAN, for assisting in the extraction process and phytochemical test.

\section{References}

[1] Frausin G, Lima RBS, Hidalgo AF, Ming LC, Pohlit AM. (2015). Plants of the Araceae family for malaria and related diseases: a review. Revista Brasileira de Plantas Medicinais, 17 (4), 657 666. 
[2] Arditti J, Rodriguez E. (1982). Dieffenbachia: uses, abuses and toxic constituents: a review. Journal of Etnopharmacology, 5 (3), 293 - 302

[3] Khaksar G, Treesubsuntorn C, Thiravetyan P. (2017). Effect of exogenous methyl jasmonate on airborne benzene removal by Zamioculcas zamiifolia: The role of cytochrome P450 expression, salicylic acid, IAA, ROS and antioxidant activity. Enviromental and Experimental Botany, 138, $130-138$.

[4] Sriprapat W, Boraphech P, Thiravetyan P. (2014). Factor affecting xylene-contaminated air removal by the ornamental plant Zamioculcas zamiifolia. Enviromental Science and Pollution Research International, 21 (4), 2603 - 2610.

[5] Le Moullec A, Juvik O.J, Fossen T. (2015). First identification of natural products from the african medicinal plant Zamioculcas zamiifolia. Fitoterapia, 106: 280 - 285.

[6] Sarker SD, Latif Z, Gray AI. (2006). Methods in Biotechnology, Natural Products Isolation. Edisi 2. New Jersey. USA: Humana Press Inc.

[7] Musa KH, Abdullah A, Kuswandi B, Hidayat MA. (2013). A novel high throughput method based on DPPH dry reagent array for determination of antioxidant activity. Food Chemistry, 141, $4102-4106$.

[8] McLaughlin JL, Rogers LL. (1998). The use of biological assays to evaluate botanicals. Drug Information Journal, 32, 513 - 524.

[9] Mosmann, T. (1983). Rapid colorimetric assay for cellular growth and survival: application to proliferation and cytotoxicity assays. Journal of Immunology Methods, 65: 55-63

[10] Prayong P, Barusrux S, Weerapreeyakul N. (2008). Cytotoxicity activity screening of some indigenous Thai Plants. Fitoterapia, 79, $598-601$.

[11] Waghray A, Murali AR, Menon KVN. (2015). Hepatocellular carcinoma: From diagnosis to treatment. World Journal of Hepatology, 7 (8), 1020 - 1029.

[12] Masriani, Mustofa, Jumina, Sunarti, Enawaty E. (2014). Cytotoxic and pro-apoptic activities of crude alkaloid from sengkubak (Pynarrhena cauliflora (Miers) Diels) in human breast cancer T47D cell line. Scholars Academic Journal of Biosciences, 2 (5), 336 - 340. 